\title{
The difference between theoretical and measured energy consumption in residential heating: Chilean case
}

\author{
La diferencia entre el consumo energético teórico y medido en calefacción residencial: caso \\ chileno
}

Claudia Rojo (Main and Corresponding Author)

Facultad de Ciencias, Universidad Mayor

Portugal 351, Santiago (Chile)

claudia.rojo@umayor.cl

\section{Adelqui Fissore}

Departamento de Ingeniería Mecánica, Facultad de Ingeniería, Universidad de Concepción

Casilla 160-C, Concepción (Chile)

afissore@udec.cl

\section{André De Herde}

Université catholique de Louvain, $\mathrm{LOCl}$, Architecture et Climat

Place du Levant 1, Louvain-La-Neuve 1348 (Belgium)

andre.deherde@uclouvain.be

Manuscript Code: 985

Date of Acceptance/Reception: 03.04.2018/28.09.2017

DOI: $10.7764 /$ RDLC.17.1.149

\begin{abstract}
At present, a large number of studies expose the differences between the results thrown by the classic models of energetic simulation (theoretical) and the measured data. This is strongly related to how people use energy in their households, especially when there is no automatic control over heating and ventilation systems. This will imply that the inputs, normally used in the energy simulation, do not necessarily take into account the actual use patterns of the heating and ventilation systems. This paper seeks to highlight the differences between the theoretical and measured energy consumption of Chilean homes. A set of houses, heated based on firewood, were studied in the city of Talca. The occupants of the dwellings were surveyed on the specific usage patterns of their heating systems and the quantity and characteristics of the firewood that they usually acquire. According to the results obtained, the energy consumed, on average, is about half of the expected consumption using classic models. Despite the difficulties involved in obtaining the information, it is considered necessary to deepen the real impact that public policies have on the reduction of energy consumption and air polluting emissions in the residential sector in Chile.
\end{abstract}

Key words: Theoretical and measured energy consumption, space heating, firewood.

Resumen

Actualmente, un gran número de estudios exponen las diferencias entre los resultados arrojados por los modelos clásicos de simulación energética (teóricos) y los datos medidos. Esto está fuertemente relacionado con la forma en que las personas usan la energía en sus hogares, especialmente cuando no hay un control automático en los sistemas de calefacción y ventilación. Esto implicará que los inputs, normalmente utilizados en la simulación energética, no necesariamente representen los patrones reales de uso de los sistemas de calefacción y ventilación. Este trabajo busca exponer las diferencias entre el consumo energético teórico y medido de las viviendas chilenas. Un conjunto de viviendas, calefaccionadas en base a leña, fueron estudiadas en la ciudad de Talca. Los ocupantes de las viviendas fueron encuestados sobre los patrones de uso específicos de sus sistemas de calefacción y la cantidad y características de la leña que generalmente adquieren. De acuerdo con los resultados obtenidos, la energía consumida, en promedio, es aproximadamente la mitad del consumo esperado empleando modelos clásicos. A pesar de las dificultades para obtener la información, se considera necesario profundizar en el impacto real que las políticas públicas tienen en la disminución del consumo de energía y las emisiones contaminantes del aire en el sector residencial en Chile.

Palabras clave: Consumo energético teórico y medido, calefacción residencial, leña

\section{Introduction}

For some time, there has been talk of the imminent risk of depletion of non-renewable energy resources and the political arrangements aimed at mitigating the effects of climate change. Institutions such as the United Nations, the European Commission and the International Energy Agency (IEA), among many other organizations have addressed the issue. For this reason, energy saving has permeated the different sectors of energy consumption such as industry, transport and building sector. 
In the last decades, the modelling of the energy required by a building has gained an important place in the analysis of the buildings sector. According to IEA (International Energy Agency, 2013), there are six factors that directly influence the building energy consumption. Three of them are related to the structure and location of the house (climate, building envelope and service building). The other three are related to the influence of the user behavior within buildings (occupant's activities and behaviour, indoor environmental quality provided and the operation and maintenance of the building).

Through the development of technology, modelling programs have become increasingly robust, allowing for an estimation of better results. In addition, global challenges for the rational use of energy create favourable conditions for the use of these models as guidance tools in decision-making.

According to Kavgic, Mavrogianni, Mumovic, Summerfield, Stevanovic, \& Djurovic-Petrovic (Kavgic et al., 2010) the analysis of any Energy Efficiency (EE) strategy requires assessment tools that are the most robust and accurate as possible and that these instruments are as reliable a reference as possible to establish the accuracy of the measurement of the energy saving.

Description of the Problem

In spite of the above, a non-negligible gap has been detected between the expected energy and that which is actually consumed. This is mainly due to the ignorance of how some factors interact with each other (Wei, Jones, \& de Wilde, 2014; Yan, O’Brien, Hong, Feng, Burak Gunay, Tahmasebi, \& Mahdavi, 2015). It is well known that building energy consumption is a complex reality to model. In fact, the quality of the input and their interrelationships play a key role in modelling of residential energy consumption. However, given the multiple variables involved and their different characteristics, models with different levels of complexity can be constructed using the available information, which should have a close relationship with the goal of modelling.

According to research by Ryan \& Sanquist (2012), energy building assessments lack, to a large extent, of detailed studies that validate their results with real cases. According to the researchers, in general, the models that have been validated correspond to the "idealized cases under specific ranges of conditions, which exclude real life conditions such as the effects of building occupants on energy usage" (Ryan \& Sanquist, 2012, p. 375). Indeed, it seems that by trying to simplify the relationship between energy - building - climate, the action that certain variables can exert on this relationship, has been underestimated.

State of the Art

Currently, several studies have reported differences in energy consumption obtained through the use of energy models and the measured consumption in the field, mainly because of human behaviour (Ahn \& Park, 2016; Audenaert \& Briffaerts, 2011; Bahaj \& James, 2007; Emery \& Kippenhan, 2006; Guerra Santin, 2011; Hiller, 2012; Huebner, McMichael, Shipworth, Shipworth, Durand-Daubin, \& Summerfield, 2013; Pan, Wang, Wei, Xu, Zhang, Xie, de Wilde, 2017; Seryak \& Kissock, 2003; Yohanis, Mondol, Wright, \& Norton, 2008).

At the end of the 1990s, Haas, Auer, \& Biermayr (1998) warned the Austrian Government of the evolution of measured consumption in this country, after the work of thermal renovation. By underestimating the relationship between occupants and energy, measured consumption did not decrease as expected. Indeed, the authors point out that there is an increase of between $15 \%$ and $30 \%$ of the energy consumption for heating in Austrian households that have adopted this type of EE measures. The authors also found that the increase depend on the initial quality of houses. The reason for this increase can be explained by the reduction of the annual costs for heating, resulting from a better energy performance of the house, favoring a higher demand for heating (Hens, Parijs, \& Deurinck, 2010) in order to improve the thermal comfort inside the houses (Sunikka-Blank \& Galvin, 2012).

Ultimately, residents do not necessarily limit their budget for heating. Haas et al. (1998, p. 195) point out that in this case, "this increase will outweigh the conservation effect to a large extent and, hence, make conservation programs useless". This phenomenon is known in the literature as 'rebound' effect and other researchers have supported the presence of such a phenomenon through their studies (Galvin, 2015; Guerra Santin, 2013; Lin \& Liu, 2015). On the other hand, Sunikka-Blank \& Galvin (2012) indicate the presence of the opposite phenomenon in German households. According to the authors, this phenomenon is known as the 'pre-bound' effect, which would appear before housing has undergone a thermal renovation. In this particular case, the overall theoretical energy consumption is higher than the estimated consumption based on actual data. According to the study, German households consume around $30 \%$ less than the estimated consumption for heating. In addition, the authors point out that the greatest differences between 
theoretical and measured consumption occur in homes whose energy classification is less efficient. For example, a house that should consume $300 \mathrm{kWh} / \mathrm{m}^{2}$ year, only consumes $180 \mathrm{kWh} / \mathrm{m}^{2}$ a year, while other households where consumption is expected to be $125 \mathrm{kWh} / \mathrm{m}^{2}$ a year, measured consumption rises to $150 \mathrm{kWh} / \mathrm{m}^{2}$ a year (Sunikka-Blank \& Galvin, 2012). A comparable phenomenon has been reported in houses in Netherlands and France (Cayre, Allibe, \& Laurent, 2011; Tigchelaar, Menkveld, \& Daniëls, 2011).

In Chile, the differences between expected and measured consumption are also important. This is the case of the study carried out by Fissore \& Colonelli (2012) where the theoretical and measured energy consumption for residential heating was compared. This study evaluated 75 low-income housing before and after applying the thermal renewal program promoted by the Chilean Government. The objective was to determine the energy-saving potential through the implementation of the program. However, the results show a great discrepancy between the values collected through surveys and those values thrown by a calculation model. In fact, before thermal renewal, the difference between the theoretical and measured results, on average, is about $108 \%$. In other words, in this case, theoretical consumption is twice as much as measured consumption.

A similar situation was found in the study of Universidad de Concepción (Universidad de Concepcion, 2014). This time, 43 households were assessed in the VII Region of the country to obtain the information necessary to develop an environmental decontamination plan. The existing thermal characteristics and residential heating systems commonly used were evaluated. Then, the energy consumption for heating was calculated using two approaches: using a classic calculation model and measurements of energy consumption in the field. By comparing the two approaches, the average differences reached $136 \%$. In conclusion, the gap between theoretical and measured consumption is not an isolated incident. According to the IEA, this difference has its origins in the lack of understanding of how energy is used in real life. In addition, "the reasons for this divergence are generally poorly understood and often have more to do with the role of human behaviour than with building design" (International Energy Agency, 2013, p.7). From that perspective, the characterization of key data concerning the use of energy in homes can help improve the results of a model of calculation, reducing the gap with those obtained in reality.

For this reason, this research seeks to highlight the gap between theoretical and measured energy consumption for heating in Chilean households.

Methodology

As previously reported, occupants' behaviour is an element that can influence significantly the energy consumption of buildings. Although dynamic thermal simulation software offers a number of possibilities to integrate the occupation profile, they are generally only used to present standardized data, which often do not represent the real situation. Therefore, the results obtained from energy simulations that incorporate that sort of data, do not necessarily represent the analysed context.

In order to evaluate the differences between the theoretical and measured consumption of a set of houses, 20 surveys were carried out in the city of Talca, by the project "Diagnóstico de la calidad del aire y medidas de descontaminación en Talca y Maule" "Diagnostic of the air quality and measures of decontamination in Talca and Maule" (Universidad de Concepción, 2014). Figure 1 shows the distribution of those 20 households.

Data such as family (size, age, time spent in housing, etc.), physical characteristics of houses (built area, main materials, etc.), monthly fuel heating expenses, the amount of fuel purchased by the occupants, characteristics and usage patterns of heating system (performance, schedules, among others) and the characteristics and usage patterns of the ventilation system (schedules, type of open area, etc.) were collected. It should be emphasized that all selected homes use firewood as the main heating fuel.

In order to estimate the energy consumption for heating, the methodology described in this section considers the field data collected from household surveys. In other words, from the purchase of firewood units that people report using, the energy consumption measured is estimated. To calculate the total annual energy for heating, Equation 1 is used.

$$
E=L H V_{m} * M
$$

Where: 
$\mathrm{LHV}_{\mathrm{m}} \quad$ : lower heating value depending on the moisture content of firewood, in $\mathrm{kWh} / \mathrm{kg}$

M : mass, in $\mathrm{kg}$

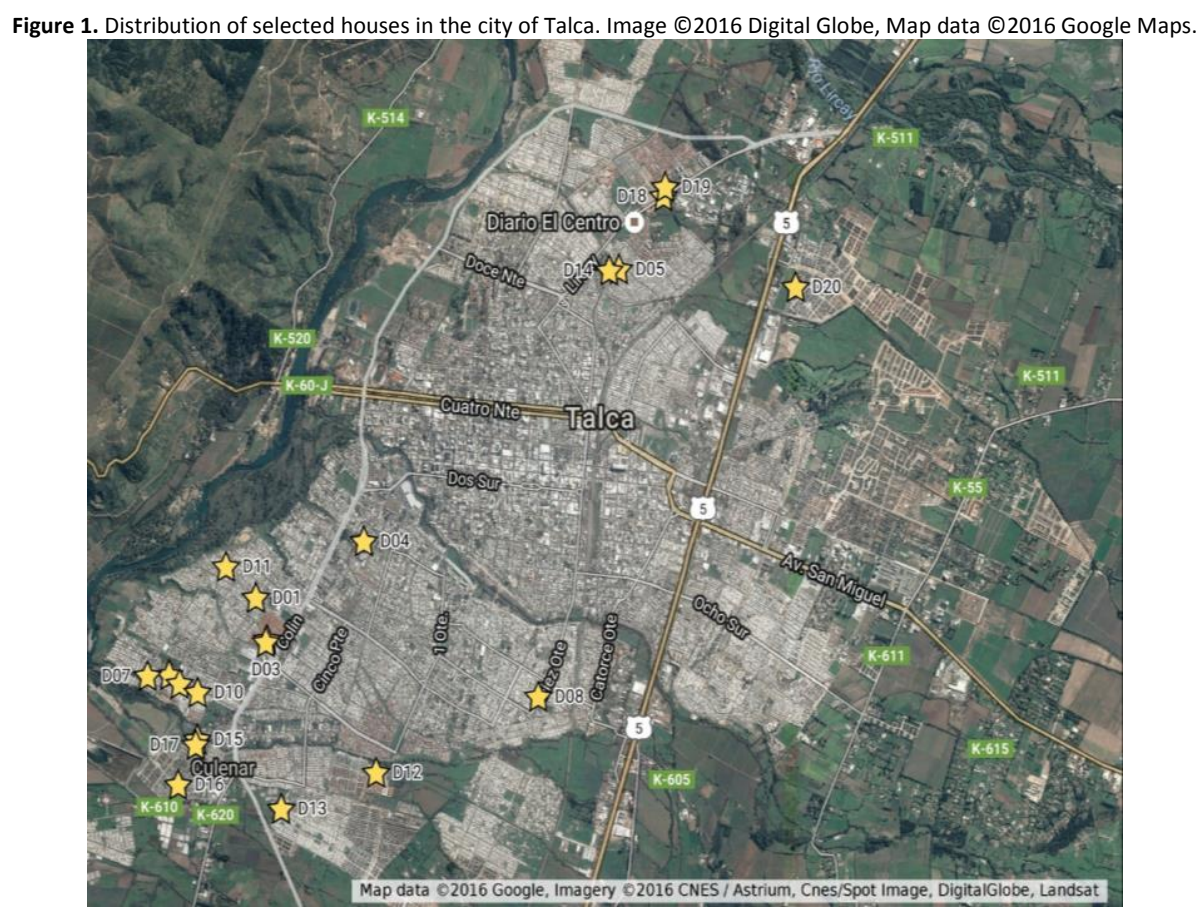

The heating value of firewood varies according to two factors: 1 ) the wood species and 2 ) the moisture content ( $\omega \%$ ) at the time of combustion. For this study, eucalyptus was the most commonly wood species used. According to the literature, the moisture content affects the heating value inversely. However, for this calculation, the LHV is considered constant for the values corresponding to the moisture content equal to or below $25 \%$. Then, Equation 2 shows the corresponding relationship between $\mathrm{LHV}_{\mathrm{m}}$ and $\omega \%$, as shown in Figure 2.

$L H V_{m}=1.17 *\left(L H V_{0}-0.0476 * \omega\right)$

Where:

$\mathrm{LHV}_{\mathrm{m}} \quad$ : lower heating value depending on the moisture content of firewood, in $\mathrm{kWh} / \mathrm{kg}$

$\mathrm{LHV}_{0} \quad$ : lower heating value for dry firewood, $4.71 \mathrm{in} \mathrm{kWh} / \mathrm{kg}$

$\% \omega \quad$ : moisture content of firewood, in percentage

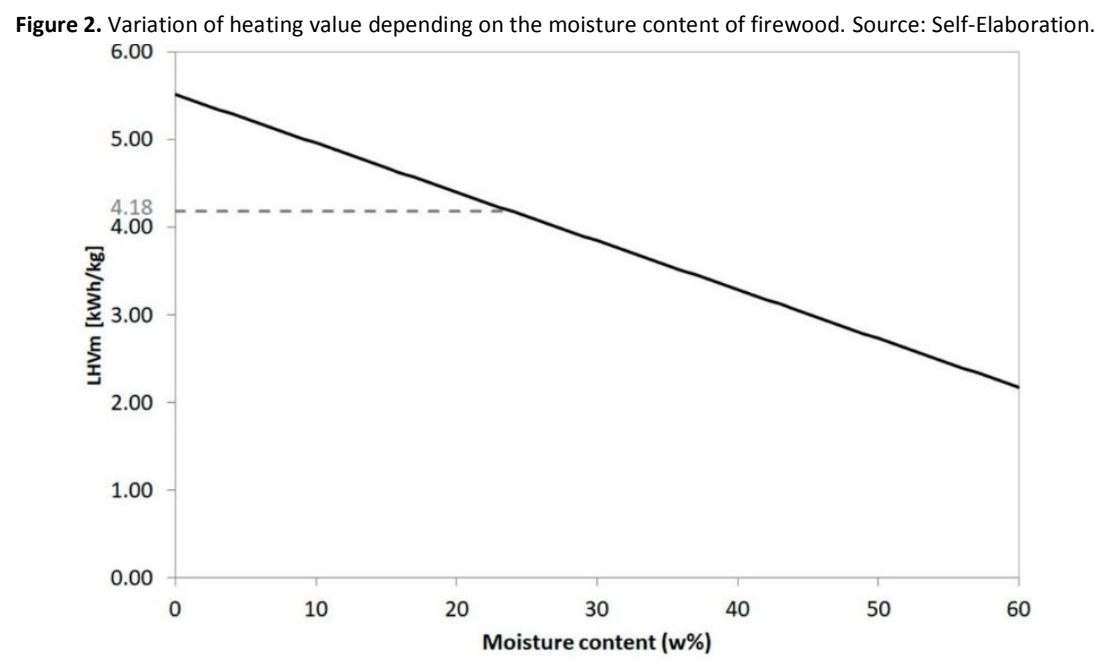

During the study, the residents were invited to comment about the moisture content of firewood bought in 2013 . To facilitate the response, they had the possibility to choose among three levels of moisture content shown in the left 
column of the Table 1. The right column shows the humidity range corresponding to each level. These values were not presented to residents at the time of the survey.

Table 1. Correspondence between levels and moisture content. Source: Compiled from Ministerio de Energía (n.d.)

\begin{tabular}{lc}
\hline Levels & Moisture Content $[\% \omega]$ \\
\hline Dry wood & $\% \omega<25$ \\
Semi-humid wood & $25 \leq \% \omega \leq 40$ \\
Humid wood & $\% \omega>40$ \\
\hline
\end{tabular}

The answers were complemented by queries regarding storage conditions and preferences of the firewood supply. In addition, during the survey, the moisture percentage of the stored firewood was measured in each of the houses.

The values in table 1 were compared with the additional information obtained. Thus, the moisture content of the firewood used for the calculation of $\mathrm{LHV}_{\mathrm{m}}$ was obtained. The values are presented in Table 2 of results. For calculating the amount of firewood used annually, purchase units should be considered. The survey showed an inclination of the residents to use stacked cubic metre ( $A$ unit used to measure volumes of stacked timber equal to one cubic meter (35,315 cubic feet) (“Buying firewood? Don't get burned! - Measurement Canada," n.d.)) (stacked $\mathrm{m}^{3}$ ). On the other hand, the purchase of this fuel was also carried out in sacks. According to the national literature consulted, on average, a stacked $\mathrm{m}^{3}$ weighs about $560 \mathrm{~kg}$ (John O'Ryan Surveyors S.A., 2011). Given the lack of information, this value is used to calculate the amount of kilos of firewood in all cases studied and according to the data collected, these firewood bags weigh around $40 \mathrm{~kg}$ (Rojo, 2016). In fact, obtaining these parameters has its difficulties, which will be discussed in the discussion and conclusions section.

On the other hand, a classic calculation model elaborated in TRNSYS is used in order to evaluate the differences that are obtained between the theoretical and measured energy consumptions for residential heating. This model includes inputs and variables that are closely involved with residential energy consumption such as external climate, physical characteristics of houses, internal gains and periods of both heating and ventilation typically employed in this area. For these latest data, extensive national literature available was revised (Álvarado \& González, 2014; Bobadilla, Díaz, Figueroa, \& Arriagada, 2014; Bustamante, 2004; Bustamante, Cepeda, Martínez, \& Santa María, 2009).

To estimate the energy consumption for residential heating, two points are mainly considered: 1) the amount of firewood acquired during the year and 2) the moisture content of firewood.

As it was mentioned in the previous section, the most widely used purchasing unit is the Stere. $90 \%$ of the households surveyed declared to buy stacked $\mathrm{m}^{3}$, while the remaining $10 \%$ purchase their firewood in sacks. For those 18 households that use stacked $\mathrm{m}^{3}$, the average purchase is 4.2 stacked $\mathrm{m}^{3}$ per year. While the two households that preferred to buy their firewood in bags, namely D04 and D06, the consumption was an average of 41 bags per year (Table 2).

Occupants are also consulted about the wood moisture purchased, according to the three categories: dry, semi-humid and humid. According to the survey, $90 \%$ of households report having acquired dry wood, whereas only $10 \%$ indicates having bought it semi-humid. These answers depend on the occupants' knowledge and perception of their firewood, which makes it quite subjective. Consequently, the final results could be affected. This is why, along with the questionnaire survey conducted in households, the moisture content of the stored firewood was measured, using a firewood moisture meter.

The humidity detected in the firewood, at the time of carrying out the survey, coincided largely with the answers given by the dwellers. This could be an indication that the occupants have a much clearer idea about the moisture content of firewood that they purchase. This could reduce the degree of subjectivity in the final result. However, further studies are needed to discuss the situation.

In order to calculate the amount of firewood for space heating, the $\mathrm{LHV}_{\mathrm{m}}$ is estimated according to the methodology described above. On average, for all houses, the calculated amount corresponds to $4.01 \mathrm{kWh} / \mathrm{kg}$. The average annual firewood consumption calculated is $2,238 \mathrm{~kg} / \mathrm{year}$-home. Table 2 shows the values used to estimate the measured energy consumption on the set of houses. 
Table 2. Database estimated to calculate residential heating consumption. Source: Self-Elaboration.

\begin{tabular}{|c|c|c|c|c|}
\hline House & $\begin{array}{c}\text { Surface } \\
{\left[\mathrm{m}^{2}\right]}\end{array}$ & Moisture content [\%] & $\begin{array}{c}\text { Firewood consumption } \\
\text { per year }\end{array}$ & $\begin{array}{c}\text { Weight } \\
\text { [kg] }\end{array}$ \\
\hline D01 & 61.5 & 25 & 3.0 stacked $\mathrm{m}^{3}$ & 1,680 \\
\hline D02 & 78.1 & 25 & 5.0 stacked $\mathrm{m}^{3}$ & 2,789 \\
\hline D03 & 78.0 & 25 & 3.0 stacked $\mathrm{m}^{3}$ & 1,680 \\
\hline D04 & 79.0 & 25 & 50 sacs & 2,000 \\
\hline D05 & 44.0 & 25 & 2.0 stacked $\mathrm{m}^{3}$ & 1,120 \\
\hline D06 & 81.0 & 25 & 32 sacs & 1,280 \\
\hline D07 & 86.0 & 25 & 6.0 stacked $\mathrm{m}^{3}$ & 3,360 \\
\hline D08 & 88.9 & 25 & 6.0 stacked $\mathrm{m}^{3}$ & 3,360 \\
\hline D09 & 58.1 & 25 & 3.0 stacked $\mathrm{m}^{3}$ & 1,680 \\
\hline D10 & 72.0 & 25 & 3.5 stacked $\mathrm{m}^{3}$ & 840 \\
\hline D11 & 66.0 & 25 & 2.0 stacked $\mathrm{m}^{3}$ & 1,120 \\
\hline D12 & 68.0 & 25 & 4.8 stacked $\mathrm{m}^{3}$ & 2,688 \\
\hline D13 & 46.2 & 25 & 1.8 stacked $\mathrm{m}^{3}$ & 1,008 \\
\hline D14 & 82.6 & 41 & 6.0 stacked $\mathrm{m}^{3}$ & 3,360 \\
\hline D15 & 74.0 & 49 & 4.0 stacked $\mathrm{m}^{3}$ & 2,240 \\
\hline D16 & 74.0 & 25 & 6.0 stacked $\mathrm{m}^{3}$ & 3,360 \\
\hline D17 & 81.0 & 25 & 6.0 stacked $\mathrm{m}^{3}$ & 3,360 \\
\hline D18 & 83.5 & 25 & 3.0 stacked $\mathrm{m}^{3}$ & 1,680 \\
\hline D19 & 107.0 & 25 & 5.0 stacked $\mathrm{m}^{3}$ & 2,789 \\
\hline D20 & 81.8 & 25 & 6.0 stacked $\mathrm{m}^{3}$ & 3,360 \\
\hline
\end{tabular}

In order to evaluate the accuracy of the values obtained in relation to the kilos of firewood used in the VII region, the National Socio-Economic Characterization survey (CASEN) of 2006 was employed. This survey is one of the few sources of information about the amount of firewood used by houses for residential heating. According to the survey data, households on average would use $2,663 \mathrm{~kg} /$ year per house. This value is quite close to the $2,238 \mathrm{~kg} / \mathrm{year}$ per house obtained in this research. For this reason, it is estimated that the values determined by this work are in the valid ranges for the region.

Finally, using Equation 1, the annual energy for residential space heating can be calculated. The value varies between 48 and $187 \mathrm{kWh} / \mathrm{m}^{2}$ year, with an average of $118 \mathrm{kWh} / \mathrm{m}^{2}$ a year for the set of houses (Figure 3). Furthermore, the inputs used in the classical model correspond to those shown in Table 3.

Table 3. Inputs inserted in a classical model. Source: Compiled from Bustamante et al. (2009).

\begin{tabular}{lccc}
\hline $\begin{array}{l}\text { Indoor temperature } \\
{\left[{ }^{\circ} \mathrm{C}\right]}\end{array}$ & $\begin{array}{c}\text { Daily Heat Period } \\
{[\mathrm{h}]}\end{array}$ & Heating Period [months] & Air infiltration rate $\left[\mathrm{h}^{-1}\right]$ \\
\hline $17-20^{1}$ & 24 & 6 & 1 \\
\hline${ }^{1}$ Between $7 \mathrm{~h} 00$ and $23 \mathrm{~h} 00$ a constant temperature was set to $20^{\circ} \mathrm{C}$. While, between $23 \mathrm{~h} 00$ and $7 \mathrm{~h} 00$, this temperature \\
was set to $17^{\circ} \mathrm{C}$.
\end{tabular}

The inputs introduced in the classical model correspond to values normally used in the Chilean literature.

Finally, the values returned by classical model are presented in Figure 3, for each of the 20 houses modelled. The values vary between 155 and $350 \mathrm{kWh} / \mathrm{m}^{2}$ year, with an average of $253 \mathrm{kWh} / \mathrm{m}^{2}$ year for the set of houses.

As it may be appreciated, the gap between the theoretical and measured consumption is important in the set of houses analyzed. In fact, the average gap established corresponds to $108 \%$ between both annual energy consumptions in residential space heating. That is, the estimated values based on the classic model correspond to twice the estimated value according to field data. 


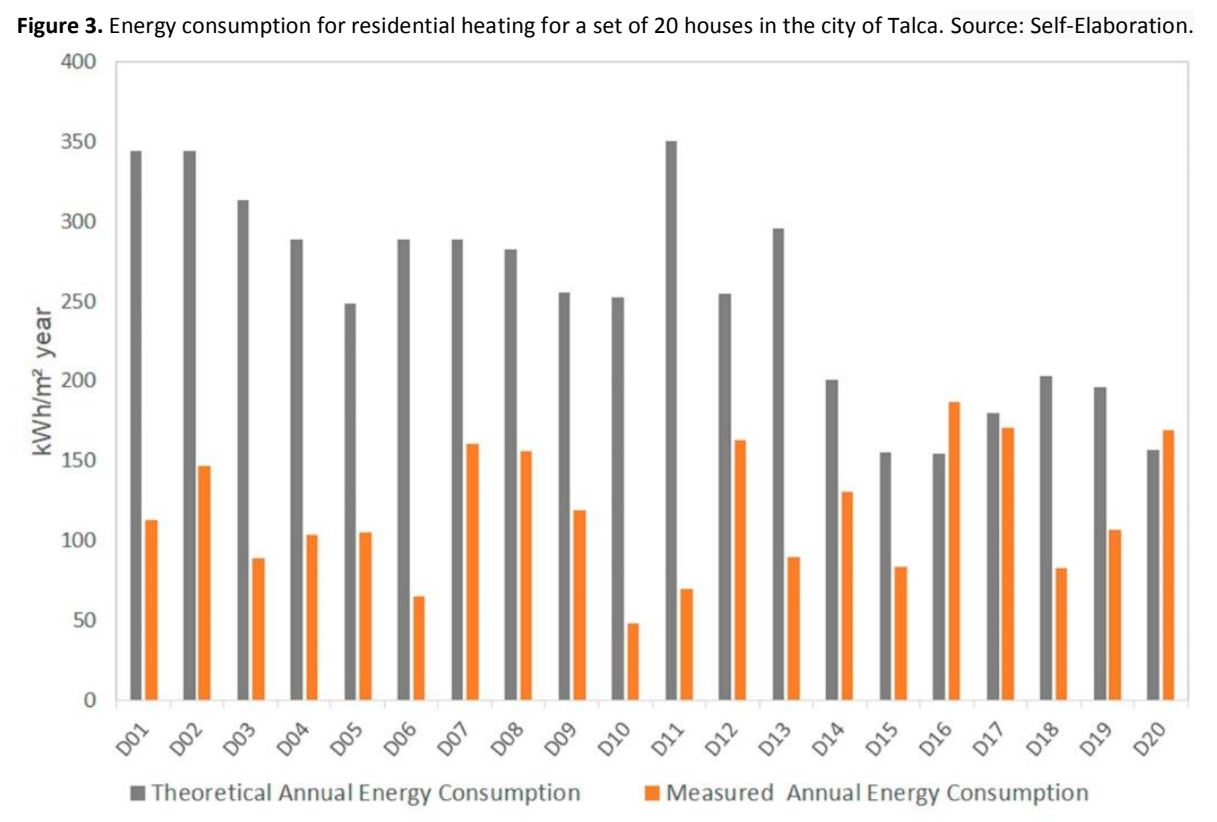

Discussion and Conclusions

As indicated in the Methodology section, one of the main challenges has been to calculate the consumption of firewood used in residential heating. For this purpose, both heating value and kilos of firewood declared by the occupants were employed. As indicated above, however, these two parameters have a degree of uncertainty due to the nature of the data. On the one hand, the heating value of firewood is closely related to the humidity rate of the wood. On the other hand, the multiple formats of purchasing this fuel such as stacked $\mathrm{m}^{3}$ and sacks, can bring important changes in the quantity of kilos estimated for calculations.

To take into account the moisture of the firewood and to reduce the error in the LHV approximation, two different approaches were followed. On the one side, the responses from the surveyed users on the humidity of the firewood purchased were considered. On the other side, moisture content of firewood was directly measured in the field during the surveys.

When comparing these two methodologies, it appears that people can easily recognize the amount of moisture (within wide ranges such as dry, semi-humid and moist) in the firewood they will use on their heating system. While this approach is still an approximation, there is currently no reliable method to better estimate the moisture content of firewood that people buy and store.

In relation to the differences from the different firewood supply units, data from two sources were used (Universidad de Concepción, 2014; John O'Ryan Surveyors S.A., 2011). Subsequently, the results were compared with data from CASEN survey 2006. In this way, you seek to validate the results obtained with the available external data. Nevertheless, it is important to note that further research is required, because the information regarding the use of firewood in the residential sector is quite limited.

Despite the difficulties faced, it is necessary to take into account these new data when current and future public policies will be analysed. On the one hand, the fact that energy consumption is lower than expected (theoretical model) could have an impact on the energy savings envisaged by the Chilean government. In fact, it is not possible to save energy which has not been consumed (Sunikka-Blank \& Galvin, 2012). On the other hand, given the poor energy performance of the houses studied, it is assumed that the thermal comfort on households is precarious, which needs to be evaluated, to take the necessary measures in order to improve the quality of life of these families.

Finally, some possible reasons for the gap between theoretical and measured energy consumption for heating in the national context are given. On the one side, the impact of the increase of indoor temperature in households' budget. On the other hand the different lifestyles that the occupants have (work schedule for example). Both could restrict the use of heating system both daily and in the annual period. 
This work was funded by CONICYT "Becas de Doctorado en el extranjero, Becas Chile, Convocatoria 2012". This research was conducted in the Architecture et Climat research team of Université Catholique de Louvain, Belgium.

References

Ahn, K.-U., \& Park, C.-S. (2016). Correlation between occupants and energy consumption. Energy and Buildings, 116, $420-433$. https://doi.org/10.1016/j.enbuild.2016.01.010

Álvarado, R. G., \& González, A. (2014). Condiciones de forma y desempeño energético de viviendas unifamiliares. Revista INVI, 28(80), 111-141.

Audenaert, A., \& Briffaerts, K. (2011). The impact of consumers behaviour on the difference between practical and theoretical domestic energy consumption for space heating. 9th IASME / WSEAS International Conference on Fluid Mechanics and Aerodynamics, FMA'11, 9th IASME / WSEAS International Conference on Heat Transfer, Thermal Engineering and Environment, HTE'11, 90-97. Retrieved from http://www.scopus.com/inward/record.url?eid=2-s2.0-83655198128\&partnerID=40\&md5=8961ab560bec9f0dce1228a277268dbc

Bahaj, A. S., \& James, P. A. B. (2007). Urban energy generation: The added value of photovoltaics in social housing. Renewable and Sustainable Energy Reviews, 11(9), 2121-2136. https://doi.org/10.1016/j.rser.2006.03.007

Bobadilla M, A., Díaz C, M., Figueroa S, R., \& Arriagada B, R. (2014). Proposal of Acceptable Air Tightness Classes for Buildings in Chile. Revista de La Construcción, 13(1), 15-23. https://doi.org/10.4067/S0718-915X2014000100002

Bustamante, W. (2004). Estudio de comportamiento térmico viviendas en diferentes ciudades de Chile. Bases para una zonificación ClimáticoHabitacional. Revista de La Construcción, 3(1), 1-13. Retrieved from http://www7.uc.cl/construc_civil/site/artic/20100304/pags/20100304163121.html

Bustamante, W., Cepeda, R., Martínez, P., \& Santa María, H. (2009). Eficiencia energética en vivienda social: un desafío posible. In Camino al Bicentenario - Propuestas para Chile (pp. 253-282). https://doi.org/10.1007/s13398-014-0173-7.2

Buying firewood? Don't get burned! - Measurement Canada. (n.d.). Retrieved September 7, 2017, from https://www.ic.gc.ca/eic/site/mcmc.nsf/eng/Im03963.html

Cayre, E., Allibe, B., Laurent, M.H., O. D. (2011). There are people in this house! How the results of purely technical analysis of residential energy consumption are misleading for energy policies. In Proceedings of the European Council for an Energy Efficient Economy (ECEEE) Summer School, 6 - 11 June 2011 (pp. 1675-1683). Belambra Presqu'île de Giens, France.

Emery, A. F., \& Kippenhan, C. J. (2006). A long term study of residential home heating consumption and the effect of occupant behavior on homes in the Pacific Northwest constructed according to improved thermal standards. Energy, 31(5), 677-693. https://doi.org/10.1016/j.energy.2005.04.006

Fissore, A., \& Colonelli, P. (2012). Evaluación Independiente del Programa de Reacondicionamiento Térmico. Chile. Retrieved from http://catalogo.bcn.cl/ipac20/ipac.jsp?profile=bcn\&index=BIB\&term=248690

Galvin, R. (2015). "Constant" rebound effects in domestic heating: Developing a cross-sectional method. Ecological Economics, 110, $28-35$. https://doi.org/10.1016/j.ecolecon.2014.12.016

Guerra Santin, O. (2011). Behavioural Patterns and User Profiles related to energy consumption for heating. Energy and Buildings, 43(10), $2662-2672$. https://doi.org/10.1016/j.enbuild.2011.06.024

Guerra Santin, O. (2013). Occupant behaviour in energy efficient dwellings: Evidence of a rebound effect. Journal of Housing and the Built Environment, 28(2), 311-327. https://doi.org/10.1007/s10901-012-9297-2

Haas, R., Auer, H., \& Biermayr, P. (1998). The impact of consumer behavior on residential energy demand for space heating. Energy and Buildings, 27(2), 195-205. https://doi.org/10.1016/S0378-7788(97)00034-0

Hens, H., Parijs, W., \& Deurinck, M. (2010). Energy consumption for heating and rebound effects. Energy and Buildings, 42(1), $105-110$. https://doi.org/10.1016/j.enbuild.2009.07.017

Hiller, C. (2012). Influence of residents on energy use in 57 Swedish houses measured during four winter days. Energy and Buildings, 54(0), 376-385. https://doi.org/10.1016/j.enbuild.2012.06.030

Huebner, G. M., McMichael, M., Shipworth, D., Shipworth, M., Durand-Daubin, M., \& Summerfield, A. (2013). Heating patterns in English homes: Comparing results from a national survey against common model assumptions. Building and Environment, 70. https://doi.org/10.1016/j.buildenv.2013.08.028

International Energy Agency. (2013). International Energy Agency, Programme on Energy in Buildings and Communities, Total Energy Use in Buildings: Analysis and Evaluation Methods, Final Report Annex 53. (H. Yoshino, Ed.). Sendai: EBC Bookshop.

John O'Ryan Surveyors S.A. (2011). Estudio comparación de precios y calidad de la leña en época de invierno en Valdivia, Temuco y Gran Concepción Informe Final. ID 608897-116-LE11.

Kavgic, M., Mavrogianni, A., Mumovic, D., Summerfield, A., Stevanovic, Z., \& Djurovic-Petrovic, M. (2010). A review of bottom-up building stock models for energy consumption in the residential sector. Building and Environment, 45(7), 1683-1697. https://doi.org/10.1016/j.buildenv.2010.01.021 
Lin, B., \& Liu, H. (2015). A study on the energy rebound effect of China's residential building energy efficiency. Energy and Buildings, 86, 608-618. https://doi.org/10.1016/j.enbuild.2014.10.049

Ministerio de Desarrollo Social. (2006). Encuesta CASEN Interactiva 2006 [online]. Retrieved from http://www.redatam.org/redchl/mds/casen/casen2006/Index.html

Ministerio de Energía. (n.d.). Buen uso de la leña. Gobierno de Chile. Retrieved from http://www.mma.gob.cl/1304/articles54981_BuenUsoLena082013.pdf

Pan, S., Wang, X., Wei, S., Xu, C., Zhang, X., Xie, J., ... de Wilde, P. (2017). Energy Waste in Buildings Due to Occupant Behaviour. Energy Procedia, 105, 2233-2238. https://doi.org/10.1016/j.egypro.2017.03.636

Rojo, C. (2016). MCH, un modèle de calcul pour mieux évaluer la consommation énergétique réelle des logements au Chili (tesis doctoral). Université catholique de Louvain, Louvain la Neuve, Bélgica. Retrieved from https://dial.uclouvain.be/pr/boreal/fr/object/boreal:173737

Ryan, E. M., \& Sanquist, T. F. (2012). Validation of building energy modeling tools under idealized and realistic conditions. Energy and Buildings, 47, 375-382. https://doi.org/10.1016/j.enbuild.2011.12.020

Seryak, J., \& Kissock, K. (2003). Occupancy and behavioral affects on residential energy use. The Solar Conference, 717-722.

Sunikka-Blank, M., \& Galvin, R. (2012). Introducing the prebound effect: the gap between performance and actual energy consumption. Building Research \& Information, 40(3), 260-273. https://doi.org/10.1080/09613218.2012.690952

Tigchelaar, C., Menkveld, M., \& Daniëls, B. (2011). Obligations in the existing housing stock: Who pays the bill? In Proceedings of the European Council for an Energy Efficient Economy (ECEEE) Summer School, 6 - 11 June 2011 (pp. 353-363). Belambra Presqu'île de Giens, France. Retrieved from http://www.ecn.nl/docs/library/report/2011/m11070.pdf

Universidad de Concepcion. (2014). Diagnóstico de la calidad del aire y medidas de descontaminación en Talca y Maule. Retrieved from https://issuu.com/cifagmaule/docs/presentacion_2012-614797-7-Ip12_17.

Wei, S., Jones, R., \& de Wilde, P. (2014). Driving factors for occupant-controlled space heating in residential buildings. Energy and Buildings, 70, 3644. https://doi.org/10.1016/j.enbuild.2013.11.001

Yan, D., O’Brien, W., Hong, T., Feng, X., Burak Gunay, H., Tahmasebi, F., \& Mahdavi, A. (2015). Occupant behavior modeling for building performance simulation: Current state and future challenges. Energy and Buildings, 107. https://doi.org/10.1016/j.enbuild.2015.08.032

Yohanis, Y. G., Mondol, J. D., Wright, A., \& Norton, B. (2008). Real-life energy use in the UK: How occupancy and dwelling characteristics affect domestic electricity use. Energy and Buildings, 40(6), 1053-1059. https://doi.org/10.1016/j.enbuild.2007.09.001 